\title{
Education Policies and Practices for Basic and Primary Education Development in Nepal
}

\author{
Bisna Acharya*
}

\begin{abstract}
Education policies are considered as the strategic link between the education's vision and day-to-day operations of education system of a nation. The comprehensive education policies allow to the decision makers and employees to understand their role and responsibilities within predefined limits. Education policies allow management to guide operations without constant management intervention. Education policies in Nepal have been considered as a predetermined course of action which is established to provide a guide toward accepted strategies and objectives. These policies identify the key activities and provide a general strategy to decision-makers on how to handle issues as they arise. Policies also help to eliminate the common misunderstandings by identifying job responsibilities and establishing boundaries for the job holders. The present study deals with the issues regarding Education Policy Practice focusing on development of basic and primary education in Nepal. Therefore, the major concern of the study is to examine the development of basic and primary education in Nepal.
\end{abstract}

Keywords: primary education, educational policy, job holders, decision-makers, and descriptive statistics

\section{Introduction}

Basic and primary education is the base for an educational career for the children. Primary education is the child's first formally organized learning and the instrument for learning of fundamental skills, understandings, attitudes, and habits essential to the educated citizen.Primary education is the instruments for eradicate illiteracy which forms a bond of common understanding and effort that gives strength to the youngers. In the primary education, children develop rapidly in mental, moral, emotional, and physical attainments. Thus, primary education is assumed to be essential for social, political, religious, economic, and cultural development of a nation (NNEPC, 1956).

Primary education comprises five years of schooling in Nepal. The existing five

\footnotetext{
${ }^{*}$ Ms. Acharya has completed Master's Degree in Education (M.Ed.) in 2008 and has been working as a faculty member of Curriculum and Evaluation in MahendraRatna Campus, Tahachal, Kathmandu since 2011. She has published 5 research articles in national journals. Now she is pursuing Ph.D. from Singhania University, India.
} 
years' primary education structure was the form of the structure of 1951 to 1971 AD. Primary education consisted of only three years of schooling during the period between 1971-1981 AD, when the National Education System Plan (NESP) was implemented in Nepal. NESP was based on its emphasis on literacy education alone at primary level and introducing pre-vocational subjects from Grade four onward (Bajracharya, Thapa\&Chitrakar, 1998).As per the Ministry of Education report 2015, the minimum entry age for primary education level was 5 years. Earlier primary education or the first level of education comprising of five years of schooling has currently been extended to additional three upper grades to make 8 years (Grade 1-8) as basic education. The school sector reform plan (SSRP) has determined that basic education as a human right as provisioned in the law and stresses on mother tongue as the medium of instruction in early grades of primary education (MoE,2015).

The Government of Nepal has launched the Basic and Primary Education Project (BEEP) in 1992, focusing on three aspects: (I) improvement in the quality of education, (ii) improvement in the access to basic and primary education, and (iii) strengthening of the administration and management of the sub-sector. In order to achieve these objectives, the project replicated a number of successful activities of the Seti Education for Rural Development Project (SERDP) and Primary Education Project (PEP). The Project serves as the government's major strategy for achieving the basic education goals for Nepal by the turn of the century (MoE, May 1997, p. 149). BPEP-II Program Implementation Plan (PIP) has proposed a legal provision for compulsory schooling with full enforcement within its program purview. The plan purposed three types of program activities for the CPE districts for the plan period: first, a trial piloting of preparation, evaluation, and approval of SIP in selected clusters; second, application of SIP approach to the structuring of the district primary education plan; and third, formulation of primary education development plans by aggregating and screening SIPs. Besides, BPEP II felt the need of piloting different modalities in SMC formation in the CPE districts (MFA, 2004, pp. 91-92).

\section{Review of Literature}

Basic and primary education has to ensure that by 2015 all children, particularly girls, children in difficult circumstances, and those belonging to disadvantaged castes and ethnic minority groups, have universal access to and participation in a completely free and compulsory primary/basic education of good quality. The term 'all children' signifies all children within 5-9 years for primary and 5 to 12 years for basic education irrespective of their gender, caste, ethnicity, or other circumstances. Nepal employed a number of strategies for universal primary and basic education.

Policies, plans, programs, and projects are always in hierarchical order and aligned with 
development activities. Hence a policy, as a set of decisions, is oriented towards a longterm purpose or a particular problem. In this regards policies have two basic functions. The reactive functions are as immediate response to an emergency, while proactive functions are pursued for reform and enhancing social well-being (Torjman, 2005).Inthe same manner, policies can be explicit or implicit, single decision or group of decisions which may set out directives for guiding future decisions, initiate or retard action, or guide implementation of previous decisions (Sapru, 2000).

Dhungana (2010) had conducted case study on Urban Poor Education: Policy and Practices in Nepal. The study was qualitative inquiry based upon the review of government policy papers, action plan, budgeting, statements, and commitments. The desk reviews were supplemented by discussions with educationists those making key contributions in the policy development. The study even explored some of the ongoing practices addressing poor urban education in the Kathmandu Valley. The Nepal interim constitution claimed the education up to secondary level assumed be citizenry right. But the policy, legislations and practices were not compatible to the constitutional motto. That demanded an extensive review of all educational policy and practices of the country.

The 1980s and 1990s saw an emphasis on Education for All. In fulfilling its mission of universal primary education, Nepal undertook the following important measures: free primary education, free textbook distribution, scholarship programs, requirement of one female teacher, continuous assessment system, removal of gender disparity, decentralized planning and piloting of free primary education to make it compulsory (CERID, 2004, p.1.).

The goal for universal primary education/basic education is to ensure that by 2015 all children, particularly girls, children in difficult circumstances, and those belonging to disadvantaged castes and ethnic minority groups, would have universal access to and participation in a completely free and compulsory primary/basic education of good quality. The term 'all children' signifies all children within 5-9 years for primary and 5 to 12 years for basic education irrespective of their gender, caste, ethnicity or any other circumstances.

The first strategy has to be brought school closer to the habitat, ensuring that a school is within easy walking distance for every child, not more than 30 minutes. Another significant strategy relates to removing economic barriers; schools are free. No regular fees are charged for registration, tuition, or school operation, and textbooks are provided free of cost. Incentives for children such as school meals, dress and free textbooks to school children need to be continued. Similarly, functional literacy and income-generating activities for parents need to be made accessible for target groups. 
Effective implementation of policy provisions such as primary education in mother tongue is still far from being realized, its implementation needs to be emphasized with appropriate provisions. Similarly, appropriate provisions still need to be developed to ensure education for children with disabilities (MoE, 2015, pp. 62-64).

The Constitution of Nepal 1990, which was formulated after the political movement completed attaining democratic rights had ensured the education right to the citizen. The constitution of 1990 had not clearly granted as education right to the people. The Constitution of Nepal (2015) has granted that every citizen shall have the right to access to basic education and every citizen shall have the right to compulsory and free basic education, and free education up to the secondary level. It signifies that basic education has been provisioned as the fundamental right of every citizen. Thus, the education policies are guidelines, and course of action of government or other institutions designed to assist, and influence consistent and transparent decision making. Influenced by national and international arrangements of culture, ideologies and economy, public policies reflect the development priorities of a country and are instruments of government employed to address the public problems. Policies, plans, programs and projects are always in hierarchical and aligned with development activities. Hence a policy, as a set of decisions, is oriented towards a long-term purpose or to a particular problem.

The reactive functions are immediate response to an emergency while proactive functions are pursued for reform and enhancing social well-being. In the same manner, policies can be explicit or implicit, single decision or group of decisions which may set out directives for guiding future decisions, initiate or retard action, or guide implementation of previous decisions. The present study is based on the education policy provisions and practices focusing on the development of present status of basic and primary education in Nepal.

\section{Research Gap}

Based on the literature review, key issues for education policy and practice have been identified as finding educational opportunities, accessing training, finding recognition of foreign credential education and training, and experience. Similarly, the other issues include awareness about education policies and processing policy documents. The responsibilities of the government of Nepal, cooperation between the Ministry of Education, other ministries, and non-governmental agencies and, diplomatic mission and their effectiveness are other pertinent issues of discussion. There is a lack of research on the difference between policyholders' expectations and perceived service regarding basic and primary education to Nepalese people. As the present situation demands the study of "Education policy and practices in Nepal: Analyzing the present 
status of basic and primary education." There has not been yet the study applying the descriptive method and the sample taken was small in the past study. Till the date, there has not been conducted such study of education policy and practices in Nepal.

\section{Research Questions}

Education policy and practices in Nepal has become one of the specific issues for creating milestone to improve literacy rate and bases for education development. The following research questions are developed to support the research study:

(i) What are the policy provisions for basic and primary education in Nepal?

(ii) What is the status of development of basic and primary education in Nepal?

\section{Research Objectives}

The general objective of the study is to examine the policy and practices prevailing in basic and primary education in Nepal. The specific objectives of this study are:

(i) To study the policy provisions for basic and primary education in Nepal.

(ii) To assess the present status of development of basic and primary education in Nepal.

This study deals with the issues regarding Education Policy and Practice in Nepal focusing on the present status of basic and primary education development. Nepal has formulated and implemented education development policies in different time interval focusing overall education development in Nepal. Therefore, the major concern of the study is to explore the development of present status of basic and primary education in Nepal.

\section{Research Methodology}

The present study attempts to investigate the education policy and practices in Nepal. The study is specially focused on the present status of basic and primary education development in Nepal. Research methodology deals the specific area where the study is conducted and data collection procedures. This study is descriptive and analytical nature based on secondary data. The descriptive and explanatory research is designed for the empirically speculating the research questions for this study. In the case of a descriptive research design, different tables and examples have been presented as necessary.

Keeping in view the objectives of this study, secondary sources of data are applied. The data collection process is an act performed by the educational researchers that provides a deeper understanding and exploration of live experiences and reality 
from the informants. The sources of secondary information are official records, publications, annual reports, policy documents, study reports related to other published and unpublished information. Government and non-government agencies and various other publications, book, journals, papers and internet. The data collected in this study is used to generate descriptive statistics as well as inferential statistics.

\section{Expected Outcome}

The paper will be produce publications in journals and published on the internet site. Similarly, the various aspects of the research that are useful and relevant to society will be published in the research journals. The findings of the study will be useful to the government of Nepal towards protecting the educational rights of children and their families in the future. This research study is expected to suggest the way of effective implementation of education policies.

\section{Results and Discussions}

\section{Policies towards the Development of Basic and Primary Education}

Nepal National Education Planning Commission laid the foundation for national education system within the framework of national unity, democracy, and the development of College of Education, 1956). The All-round National Education Commission, 1962 added nationalism and the prevailing political ideology to the national education system. However, during the period of 1956-1970, national education efforts were focused more on expanding access rather than on doctrine. The 1980s and the 1990s saw an emphasis on Education for All. In fulfilling its mission of universal primary education, Nepal undertook the following important measures: free primary education, free textbook distribution, scholarship programs, requirement of one female teacher, continuous assessment system, removal of gender disparity, decentralized planning, and piloting of free primary education to make it compulsory.

The goal for universal primary education/basic education was to ensure that by 2015 all children, particularly girls, children in difficult circumstances and those belonging to disadvantaged castes and ethnic minority groups, have universal access to and participation in a completely free and compulsory primary/basic education of good quality. The term 'all children' signifies all children within 5-9 years for primary and 5 to 12 years for basic education irrespective of their gender, caste, ethnicity or any other circumstances.

The Seventh Plan (1985-1990) recognized primary education as one of the basic needs of people and made a provision for the initiation of compulsory education by municipalities. The Plan put forth various programs such as free education up to Grade 5 , free textbook and female education, to achieve the target of primary education 
expansion policy by 2000 . However, massive illiteracy (60\%) and the low proportion of girls' participation in primary schools emerged as a challenge by the end of the plan period.

The Eighth Plan (1992-1997) reiterated the government's commitment to achieve the goal of universal primary education and raise the literacy rate to $67 \%$ by 2000 . The plan envisaged empowerment of local government bodies to launch compulsory primary education on pilot basis if, however, they decided to implement the scheme. Besides, it also made the provision of one female teacher in each primary school and literacy program for girls unable to attend formal school.

The policy of the Ninth Plan (1997-2002) was to upgrade the quality of basic and primary education with focus on gender equity and educational opportunity to disadvantaged communities. In the context of making primary education compulsory, the plan adopted the expansion policy on the basis of experiences gained from the field. The various programs envisaged in the plan document include: gradual implementation of the Continuous Assessment System, implementation of the Liberal Promotion Policy up to Grade 3 on experimental basis, preliminary effort to provide primary education in the mother tongue and simple, and efficient distribution of textbooks.

Tenth Plan (2002-2007) laid stress on decentralization for quality education, and on providing day-meal and scholarships to disadvantaged groups for attaining $90 \%$ enrolment. The implementation of free and compulsory primary education would be gradually followed as per the government proclamation and commitment. For this, the Plan made a provision for the development of institutional, managerial, and physical infrastructure framework.

To ensure free and primary education for all, the EFA Plan of Action (20012015) Nepal posed questions of reaching the disadvantaged and deprived children, removing gender disparities, and addressing the needs of various special needs for children. It also outlined the measures taken by Government of Nepal such as school improvement and expansion program, school feeding program, and special programs for girls and disadvantaged communities.

The expansion and development of quality primary education to fulfill the national commitment of 'Education for All' and increase the access of the rising number of primary school graduates to the secondary level education and develop secondary education so as to make the higher secondary level as the last destination of the school level education. Corresponding to the declared policy and international commitment of providing education to all by 2015 AD of Government of Nepal gradually implement the program of compulsory primary education and improve institutional, managerial and physical infrastructure accordingly (NPC, 2002, pp. 436- 
440).

The Education for All (EFA), Teacher Education Project (TEP), Secondary Education Support Program (SESP), Community School Support Program (CSSP) and Food for Education (FfE) were the programs implemented in line with the spirit of decentralization and community support. Recently, the Ministry of Education (MoE) has developed a Core Document for the School Sector Reform (SSR). The Core document has elaborated policy directions, articulated strategies, and introduced new sets of quality led interventions for improving governance, management and resource mobilization in school education, aiming at improving efficiency and ensuring students.' learning with restructuring the school structure as Basic Level (Grade 1-8) and Secondary Level (Grade 9 to 12) (MOE: A glimpse 2010, pp. 13-14).

\section{Status of Basic and Primary Education in Nepal}

The objective of education is not only limited to skill development of general literacy among citizens. There has been huge impact of education in socialization, and raising group recognition. Besides this, education, as a basis for social uplift of different strata of the society, plays a key role in boosting social dynamism and promoting equity. Education has remained as an indispensable means to achieve higher gross domestic product (GDP) growth as availability of skilled and productive citizens can be increased through the education. The effect of results obtained through appropriate investment made by the state in education sector as per the expectation of multidimensional roles of education in country's overall development. As per objectives of education policy, the number of enrollment of Basic Grade (1-5), (6-8) and Basic Grade (1-8) has satisfactory. The province wise net enrollment at primary and basic education has been shown in Table-1:

\section{Table-1}

Net Student Enrollment at Basic and Primary Education by Province in 2018/19

\begin{tabular}{|l|l|l|l|l|l|l|l|l|l|}
\hline \multirow{2}{*}{ Province/Level } & \multicolumn{3}{|l|}{ Basic Grade (1-5) } & \multicolumn{3}{l|}{ Basic Grade (6-8) } & \multicolumn{3}{l|}{ Basic Grade (1-8) } \\
\cline { 2 - 10 } & Girls & Boys & Total & Girls & Boys & Total & Girls & Boys & Total \\
\hline Province-1 & 274947 & 278601 & 553548 & 152679 & 151796 & 304475 & 427626 & 430397 & 923862 \\
\hline Province-2 & 379613 & 373024 & 752637 & 127620 & 123212 & 250832 & 507233 & 496236 & 1003469 \\
\hline Bagmati & 330386 & 339196 & 669582 & 192785 & 194166 & 386951 & 523171 & 533362 & 1056533 \\
\hline Gandaki & 155385 & 155677 & 311062 & 95851 & 95870 & 191721 & 251547 & 251547 & 503094 \\
\hline Province-5 & 337698 & 347981 & 685679 & 158211 & 160093 & 318314 & 500717 & 511304 & 1012021 \\
\hline Karnali & 158211 & 160093 & 318304 & 75976 & 74521 & 150497 & 234187 & 234614 & 468801 \\
\hline Sudurpashchim & 218952 & 220838 & 439790 & 108120 & 105839 & 213959 & 327072 & 326677 & 653749 \\
\hline Total & 1855192 & 1875410 & 3730602 & 758563 & 753701 & 1512264 & 2771553 & 2353740 & 5125293 \\
\hline
\end{tabular}

Source: Economic Surveys 2018/19.

The Figure 1 depicts the enrollment status of Primary education (1-5) on the basis of seven provinces. Province 2 shows the highest number of enrollment at primary education, and Karnali province reflects the lowest number of enrollment in the 
Academic year 2018/19.

Figure-1: Net student enrollment at primary grade (1-5) by Province

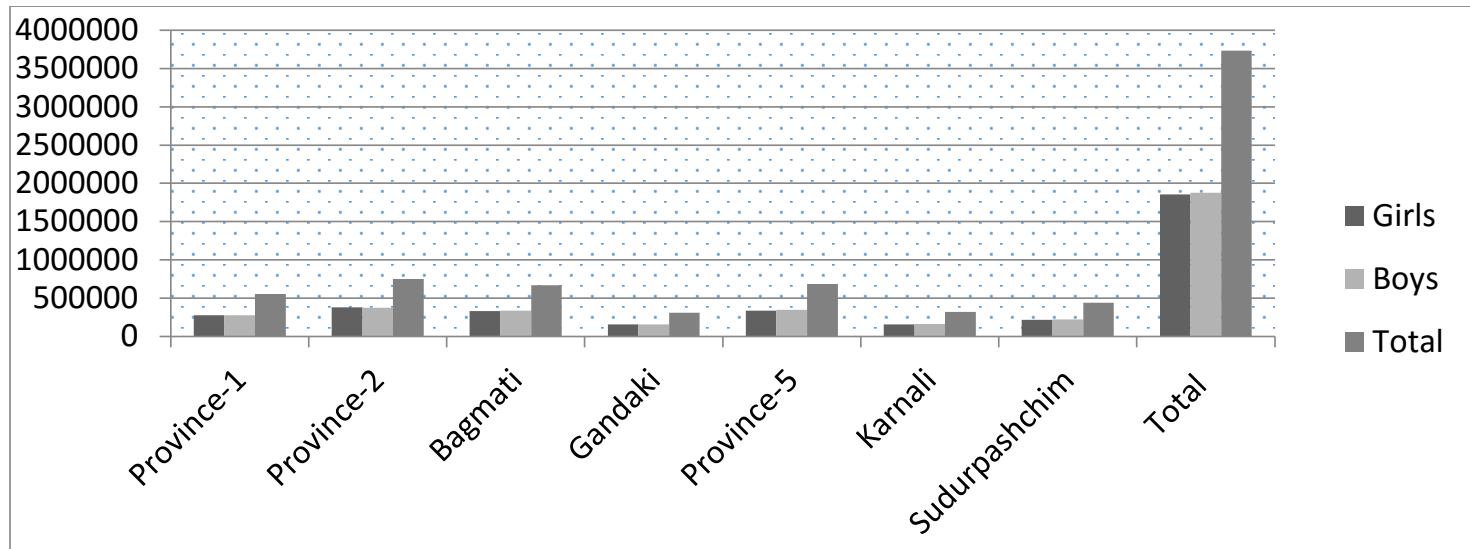

Figure-2: Student Enrollment at Basic Grade (6-8) by Province

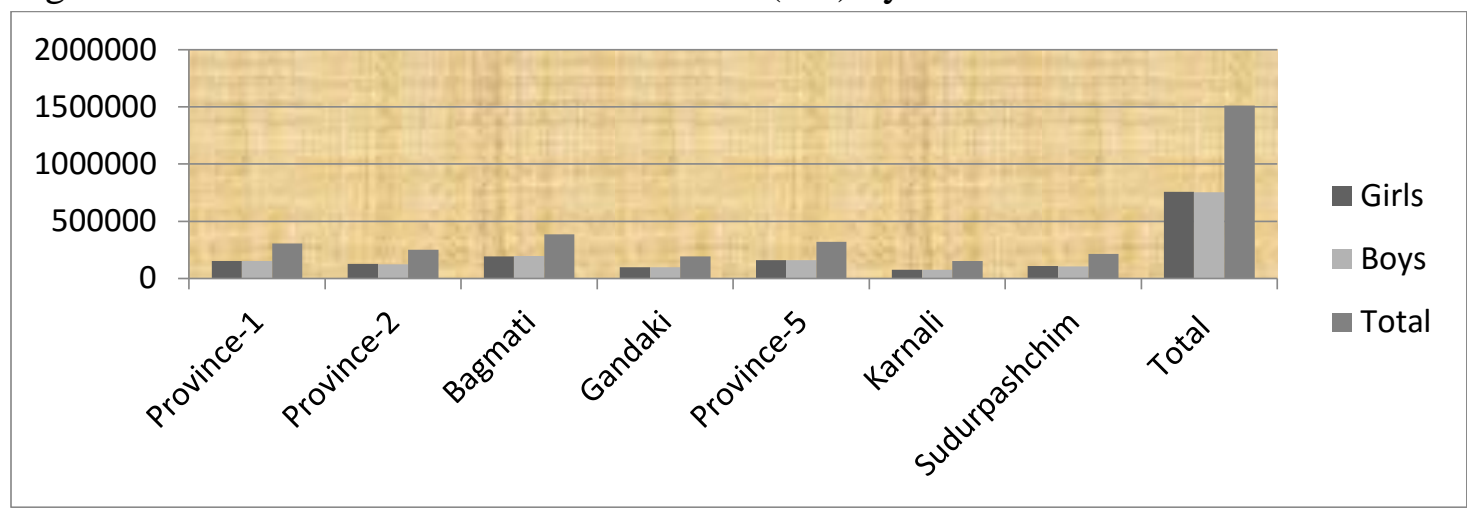

Figure-2 represents the enrollment status of Basic Grade (6-8) on the basis of seven provinces. Bagmati Province shows the highest number of enrollment at basic grade (68) whereas Karnali province reflects the lowest number of enrollment in the Academic year 2018/19.

Figure-3: Student enrollment at basic grade (1-8) by Province



Figure-3 presents the enrollment status of Basic Education (1-8) on the basis of 
seven provinces. Bagmati Province shows the highest number of enrollment at basic grade (1-8) whereas Karnali province reflects the lowest number of enrollment in the Academic year 2018/19. In the academic year 2018/19, altogether 51 lakh 25 thousand and 293 students were enrolled, whereas 54.08 percent girls and 45.92 percent of boys in the 2018/19. In the academic year 2018/19, net enrollment into primary level (grade 1-5) has reached 96.5 percent and 92.7 percent into basic level (1-8). The Net enrollment at basic and primary level seems to be satisfactory. Province 1 shows the highest rate in primary and basic level, whereas Bagmati Province depicts the lowest one in primary level (1-5) and Province 2 represents the lowest one in basic level (1-8). The trends of net enrollment rate of primary level (1-5) basic grade (6-8) and basic level (1-8) have been shown in Table 2 and figures 4, 5 and 6.

\section{Table-2}

Net Student Enrollment Rate by Province in 2018/19

\begin{tabular}{|l|l|l|l|l|l|l|l|l|l|}
\hline \multirow{2}{*}{ Province/Level } & \multicolumn{3}{|l|}{ Basic Grade (1-5) } & \multicolumn{3}{l|}{ Basic Grade (6-8) } & \multicolumn{3}{l|}{ Basic Grade (1-8) } \\
\cline { 2 - 10 } & Girls & Boys & Total & Girls & Boys & Total & Girls & Boys & Total \\
\hline Province-1 & 96.0 & 97.8 & 96.9 & 93.2 & 93.6 & 93.4 & 94.6 & 95.7 & 95.2 \\
\hline Province-2 & 94.6 & 96.4 & 95.5 & 59.3 & 68.2 & 63.8 & 77.0 & 82.3 & 79.6 \\
\hline Bagmati & 95.4 & 96.2 & 95.8 & 93.4 & 93.8 & 93.6 & 94.4 & 95.0 & 94.7 \\
\hline Gandaki & 95.3 & 96.7 & 96.0 & 93.4 & 95.2 & 94.3 & 94.3 & 96.0 & 95.1 \\
\hline Province-5 & 96.1 & 97.6 & 96.8 & 84.2 & 87.9 & 86.0 & 90.1 & 92.7 & 91.4 \\
\hline Karnali & 96.2 & 97.8 & 97.0 & 87.8 & 91.9 & 89.9 & 92.0 & 94.9 & 93.4 \\
\hline Sudurpashchim & 96.2 & 97.8 & 97.0 & 92.3 & 94.3 & 93.3 & 94.2 & 96.0 & 95.1 \\
\hline Total & 95.7 & 97.2 & 96.5 & 87.5 & 90.2 & 88.9 & 91.6 & 93.7 & 92.7 \\
\hline
\end{tabular}

Source: Economic Survey (2018/19)

Figure 4: Net student enrollment rate in primary level (1-5) by Province

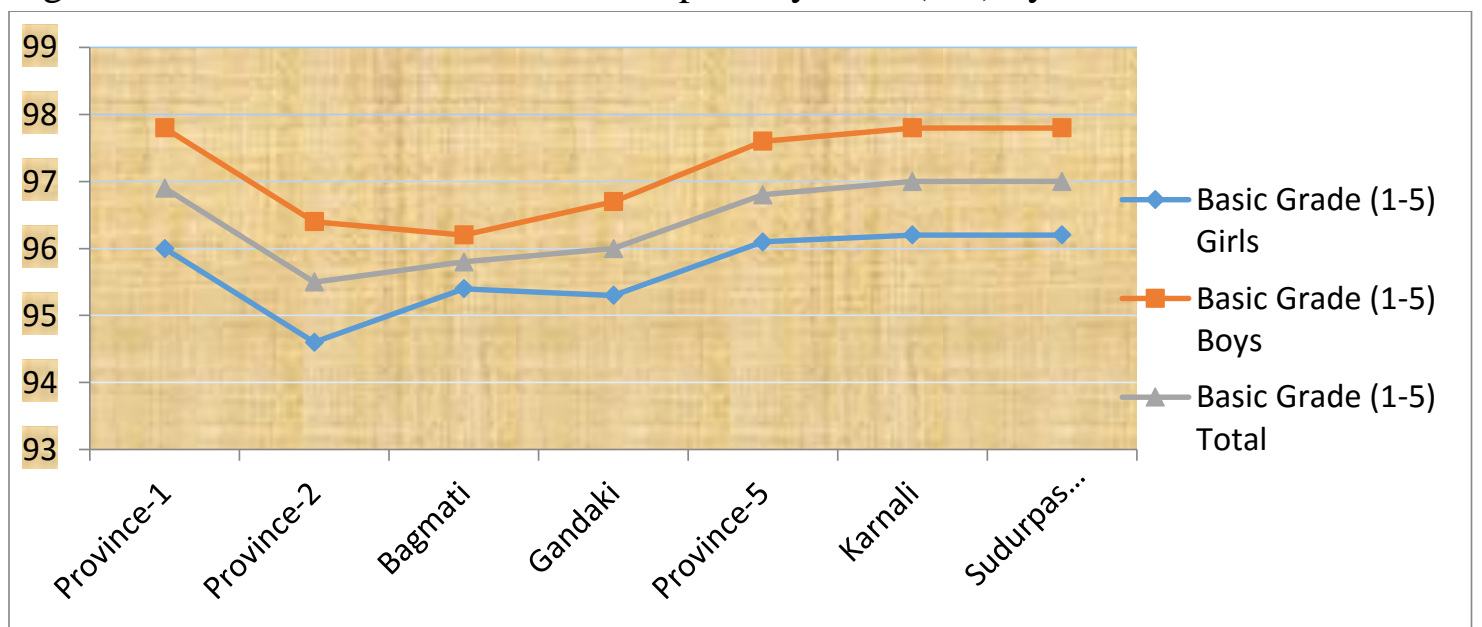

Figure-4 depicts the seven province-wise status of net enrollment of girls, boys, and 
total students net enrollment at basic grade (1-5) in the academic year 2018/19. According to data and figures, boys' net enrollment number is higher than girls' enrollment.

Figure 5: Net student enrollment rate in primary level (6-8) by Province

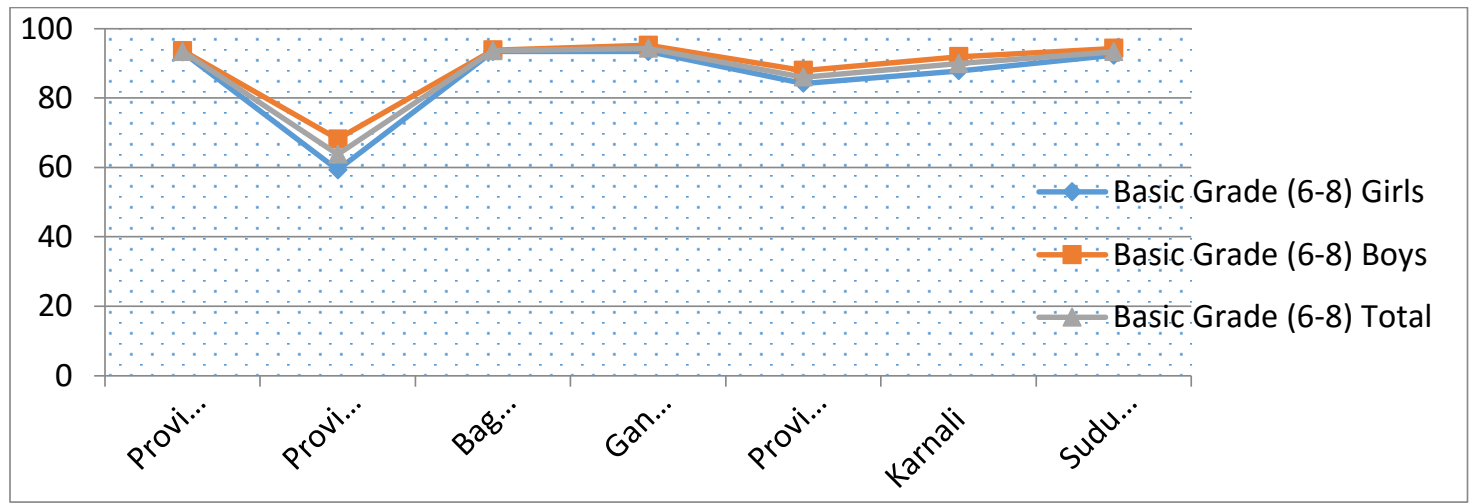

Figure-5 depicts the seven province-wise status of net enrollment of girls, boys and total students net enrollment at basic grade (6-8) in the academic year 2018/19. According to data and figures, the net enrollment rate of boys and girls seems cross rate.

Figure 6: Net student enrollment rate in basic level (1-8) by Province

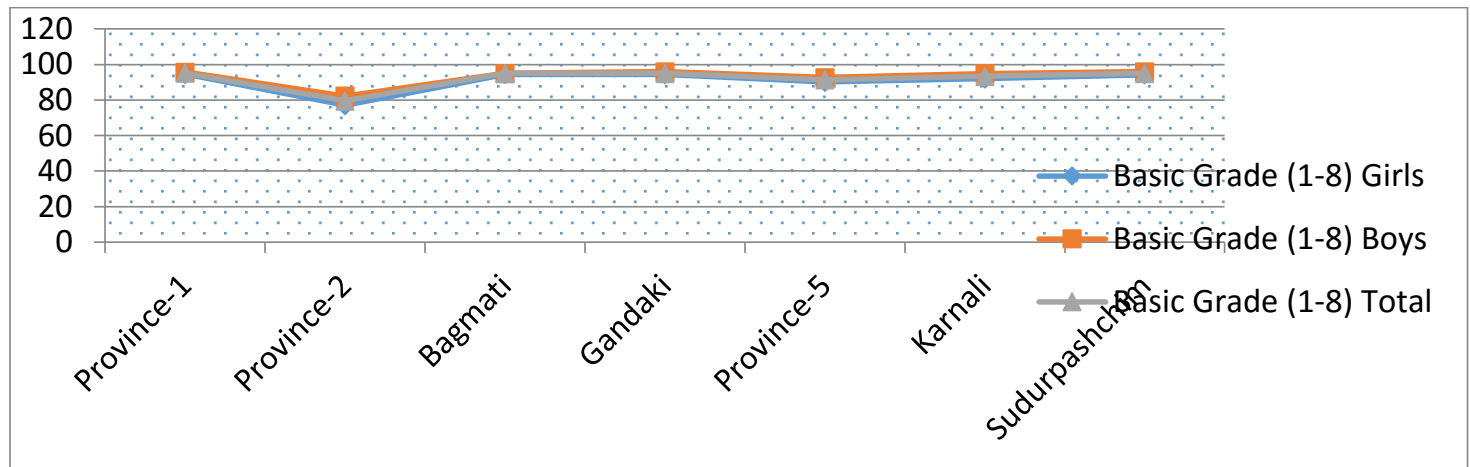

Figure-6 represents the seven province-wise net enrollment status of girls, boys, and total students net enrollment at basic grade (1-8) in the academic year 2018/19.

According to data and figures, the net enrollment rate of boys and girls seems similar to this level.

\section{Conclusions}

Education policies show what a country has been prioritizing and what resources have been invested by a country to achieve predetermined education development objectives. Thus, the education policies are guidelines as well course of the action of the government or other institutions designed to assist, and influence consistent and transparent decision making. Influenced by national and international arrangements of culture, ideologies and economy, public policies reflect the development priorities of a 
country and are instruments of government employed to address the public problems. Policies, plans, programs and projects are always in hierarchical and aligned with development activities. There is also a need for assessment on education policy and practice and necessary to understand the impact of policies on basic and primary education development, and the effectiveness of the implementation mechanism, find out the causes seen on various occasions related to the concerned policies that have virtually made the present policy less relevant, find out the relevance of the need to adapt education policy to the changing regional and international environment, analysis on the need to provide integrated support and incentive package to education sectors with a view to enhancing their competitive strength at home and abroad and review the education policies of different plan periods for the betterment.

\section{References}

Bajracharya, H.R., Thapa, B. K. \& Chitrakar, R. (1998).Trends, issues and policies of education in Nepal. Kathmandu: CERID, Tribhuvan University, pp. 3-4.

CERID (2004). Free and compulsory primary education in the context of education for all. Kathmandu: CERID, Tribhuvan University.

Dhungana, P. (2010). Urban poor education: Policy and practices in Nepal.

Kathmandu: HOMENET Nepal.

Government of Nepal. (2010). Ministry of Education: A glimpse. Kathmandu:Ministry of Education Monitoring, Evaluation and Supervision Division, Research and Education Management Information Section (REMIS).

Ministry of Education (1999). Education for all 2000 Assessment. Country Report of Nepal. Kathmandu: Ministry of Education.

Ministry of Education (2003). Education for all. National Plan of Action. Kathmandu: Ministry of Education.

Ministry of Education (2015).Education for all: National Review Report 2001-2015. Kathmandu: Ministry of Education, pp. 62-64.

Ministry of Education (2015). Education for All: National Review Report 2001-2015. Government of Nepal, Kathmandu, Nepal.

Ministry of Education/GoN (2010).A glimpse. Kathmandu: Ministry of Education Monitoring, Evaluation and Supervision Division, Research and Education Management Information Section (REMIS).

Ministry of Finance (2015). Economic Survey 2015/16. Kathmandu: Government of Nepal.

Ministry of Finance (2016). Economic Survey 2016/17. Kathmandu: Government of Nepal.

Ministry of Finance (2017). Economic Survey 2017/18. Kathmandu: Government of 
Nepal.

Ministry of Finance (2018). Economic Survey 2018/19. Kathmandu: Government of Nepal

Ministry of Foreign Affairs (MFA, 2004). Donor evaluation of basic and primary education program II. Kathmandu: Nepal Joint Government, DANIDA.

Moe/ BPEP (May, 1997). The basic and primary education master plan for 1997-2002. Kathmandu: Ministry of Education.

National Planning Commission (1956). Education in Nepal. Kathmandu: College of Education.

National Planning Commission (1997). Ninth Five Year Plan 1997-2002. Kathmandu: Government of Nepal.

National Planning Commission (2002).Tenth Five Year Plan 2002-2007. Kathmandu: Government of Nepal.

National Planning Commission (2007).Eleventh Three Year Plan 2007-2010. Kathmandu: Government of Nepal.

Research Center for Education Innovation and Development (2004). Free and compulsory primary education in the context of education for all. Kathmandu: Tribhuvan University.

Sapru, R. K. (2000). Public policy: Formulation, implementation and evaluation. New Delhi: Sterling Publishers Pvt. Ltd.

Secretariat of Constitution Assembly (2015). Constitution of Nepal 2015. Kathmandu: Government of Nepal, p. 14.

Torjman, S. (2005). What is policy?'Canada: The Caledon Institute of Social Policy. UNESCO (2011). World data on education, VII Ed. 2010. United Nations Educational, Scientific and Cultural Organization. 